\title{
Tyrosine Kinase Inhibitors for EGFR Gene Mutation-Positive Non-Small Cell Lung Cancers: An Update for Recent Advances in Therapeutics
} Clement Chung ${ }^{1,2 *}$

${ }^{1}$ Lyndon B Johnson General Hospital, USA

${ }^{2}$ Harris Health System, USA

\begin{abstract}
The presence of activating gene mutations in the epidermal growth factor receptor (EGFR) of non-small cell lung cancer (NSCLC) patients is predictive (improved progression-free survival and improved response rate) when treated with small molecule tyrosine kinase inhibitors (TKls) such as gefitinib, erlotinib and afatinib. The two most common mutations that account for greater than $85 \%$ of all EGFR gene mutations, are in-frame deletions in exon 19 (LREA deletions) and point mutations in exon 21 (L858R). Exon 18 mutations occur much less frequently at about $4 \%$ of all EGFR gene mutations. Together, deletion 19 and $L 858 R$ gene mutations are present in about $10 \%$ of Caucasian patients and $20-40 \%$ of Asian patients with NSCLC. T790M gene mutation at exon 20 is associated with acquired resistance to EGFR TKIs. Early studies showed that activating EGFR gene mutations are most common in patients with adenocarcinoma histology, women, never smokers and those of Asian ethnicity. A recent multi-center phase III trial suggested that frontline EGFR TKI therapy with afatinib is associated with improved progressionfree survival compared to chemotherapy regardless of race. Moreover, guidelines suggest EGFR testing should be conducted in all patients with lung adenocarcinoma or mixed lung cancers with an adenocarcinoma component), regardless of characteristics such as smoking status, gender, or race. The success of targeted therapies in NSCLC patients has changed the treatment paradigm in metastatic NSCLC. However, despite a durable response of greater than a year, resistance to EGFR TKIs inevitably occurs. This mini-review describes the clinically significant EGFR gene mutations and the efficacy of small molecule EGFR TKIs as targeted therapies for these gene mutations. Therapeutic strategies to overcome resistance, including selected emerging and novel therapies are discussed.
\end{abstract}

Keywords: EGFR; TKI; Afatinib; Lung adenocarcinoma; Targeted therapy; Exon 19 deletion; Exon 21; L858R; Gene mutations

\section{Introduction}

Lung cancer is a leading cause of cancer death in the U.S. In 2014, an estimated 16,000 deaths are expected to occur because of the disease [1]. Lung cancer is usually diagnosed at an advanced stage and because of this, the overall five-year survival is only 15\% [2]. Primary tumor in anatomic/clinical stages I to IIIA is considered respectable. Treatment option generally consists of surgery with or without adjuvant chemotherapy [3]. Tumor in the stage IIIB is no longer resectable and the treatment option is chemoradiation [4] whereas for stage IV, treatment options include chemotherapy or oral targeted therapy agents [5]. Chemotherapy typically consists of a platinum-based doublet therapy (i.e. cisplatin or carboplatin combined with agents such as gemcitabine, vinorelbine or taxanes and most recently, cisplatin-pemetrexed for non-squamous lung cancer). No regimen has proven superiority over another [6]. Common symptoms of lung cancer include weight loss, cough, dyspnea and chest pain. Symptomatic patients are more likely to have chronic obstructive pulmonary disease. Non-small cell lung cancers (NSCLC) account for about $85 \%$ of all lung cancers and they can be squamous (epithermoid) or non-squamous (including adenocarcinoma, large cell and other subtypes). Adenocarcinoma is the most common lung cancer type in the U.S. and in non-smokers [2].

\section{EGFR Signaling Pathway}

Epidermal growth factor receptor (EGFR; also known as HER1) is a $170-\mathrm{kDa}$ transmembrane receptor tyrosine kinase (RTK) with an extracellular ligand-binding domain, a lipophilic transmembrane region and an intracellular regulatory domain with tyrosine kinase activity [7]. EGFR is normally found on the surface of epithelial cells and is often over-expressed in many malignancies [8,9]. In addition, somatic gene mutations in the intracellular kinase domain of the EGFR lead to ligand-independent activation of the signaling pathway, leading to constitutively activated tyrosine kinase that results in tumorigenesis [10]. In normal cells, the EGFR pathway is tightly regulated whereas loss of regulation leads to uncontrolled growth and oncogenesis [11].

EGFR is the prototypical member of a family of four RTKs, EGFR (ERB-B1, HER1), ERB-B2 (HER2/Neu), ERB-B3 (HER3) and ERB-B4 (HER4) [12]. Multiple ligands activate different family members of EGFR. Ligand binding enables homo- or heterodimerization that results in intracellular tyrosine kinase domain activation and phosphorylation. This in turn creates docking sites for a diverse set of cytoplasmic signaling molecules and results in the activation of two key intracellular signaling pathways: the mitogen-activated protein kinase (MAPK) and the phosphatidylinositol-3-kinase/protein kinase B (PI3K/AKT) pathways. When stimulated, RAS protein, which is the first part of the MAPK pathway, exchanges GDP for GTP and sequentially activates RAF, followed by MEK (mitogen-activated, extracellular signalregulated kinase) and MAPK. Alternatively, ligand-bound EGFR can translocate PI3K to the cell membrane and activate AKT and other downstream molecules [13]. Tumor cells can upregulate the EGFR pathway through mechanisms such as EGFR over expression, EGFR gene amplification, activating also (known as sensitizing) mutations of

*Corresponding author: Clement Chung, Hematology/Oncology Clinical Pharmacist Specialist, Lyndon B Johnson General Hospital, 5656 Kelley St., Houston, TX 77026; Harris Health System, USA, Tel: 713-566-5664; E-mail: clement_t_chung@yahoo.com

Received September 30, 2014; Accepted November 24, 2014; Published December 01, 2014

Citation: Chung C (2014) Tyrosine Kinase Inhibitors for EGFR Gene Mutation-Positive Non-Small Cell Lung Cancers: An Update for Recent Advances in Therapeutics. J Pharmacovigilance 2: 155. doi:10.4172/2329-6887.1000155

Copyright: (c) 2014 Chung C. This is an open-access article distributed under the terms of the Creative Commons Attribution License, which permits unrestricted use, distribution, and reproduction in any medium, provided the original author and source are credited. 




The EGFR gene is located in the short arm of chromosome 7. It contains 28 exons. Exons $18-21$ are in the cytoplasmic tyrosine kinase domain of the EGFR receptor are commonly associated with sensitivity or resistance to EGFR TKIs when these genes are mutated.

The most prevalent EGFR gene mutations are Exon 19 deletion (45\%), followed by the L858R mutation in exon 21 (40\%). Exon 18 mutations (G719 S/C/A) account for approximately $4 \%$ of the overall gene mutations.

All gene mutations shown above are associated with sensitivity and hence they are predictive biomarkers for response to EGFR TKIs. T790M accounts for approximately $1 \%$ of primary resistance to EGFR TKIs. Another primary resistance to EGFR TKIs is due to insertions in exon 20 (about $4 \%$ of all gene mutations, not shown in diagram).

Key: $\mathrm{G}=$ Glycine; $\mathrm{S}=$ serine; $\mathrm{C}=$ cysteine; $\mathrm{A}=$ =alanine; $\mathrm{T}=$ threonine; $\mathrm{M}=$ methionine; $\mathrm{L}=$ leucine; $\mathrm{R}=$ arginine; $\mathrm{Q}=$ glutamine. The numbers below the vertical bar of each box refers to the amino acid number of each exon.

Figure 1: Frequency of gene mutations in exons 18-21 of the EGFR gene.

the receptor or any downstream proto-oncogene (e.g. RAS, RAF) that results in the constitutive activation of the pathway, leading to tumor growth and proliferation [14].

\section{Activating or Sensitizing Mutations of the EGFR Gene}

In NSCLC patients, the most commonly found EGFR gene mutations (that account for more than $90 \%$ of all EGFR gene mutations) are present in the first four exons (i.e. exon 18-21) of the gene encoding the tyrosine kinase domain which binds to the substrate ATP. These EGFR gene mutations (Figure 1) are:

- Exon 19 deletion (i.e. in-frame conserved deletions that encompass 4 amino acids on amino acid positions $747-750$ or the "LREA" region) that occurs in $45 \%$ of patients with EGFR gene mutations. These 4 amino acids are: leucine (L), arginine (R), glutamic acid (E) and alanine (A) [15].

- Exon 21 L858R gene mutation (a mis-sense mutation that results in a substitution of leucine with arginine at amino acid position 858) that occurs in another $40 \%$ of patients with EGFR gene mutations [16].

- Exon 18 G719X gene mutation (a mis-sense mutation that results in the substitution of glycine with cysteine, alanine or serine at amino acid position 719 ) that occurs in about $4 \%$ of all EGFR gene mutated patients. Other drug-sensitizing gene mutations include point mutations at exon 21 [17].

- T790M mutation, a secondary point mutation (developed after initial therapy with TKIs) located at exon 20 that results in substitution of methionine ( $\mathrm{T}$ ) for threonine $(\mathrm{M})$ at amino acid position 790, is associated with acquired resistance to TKI therapy in $50-60 \%$ of patients with adenocarcinomas of the lung [18].

Resistance to small molecule EGFR tyrosine kinase inhibitors (TKI) can be either primary or acquired. Patients with primary resistance are refractory to upfront TKI treatment, whereas acquired or secondary resistance occurs after an initial response. Common acquired resistance mechanisms to EGFR TKIs are T790M mutation, transformation of the NSCLC to small cell lung cancer (SCLC) and the mesenchymal-epidermal transition (MET) receptor overexpression or gene amplification. Of interest, MET gene amplification is observed in $20 \%$ of resistance cases in NSCLC patients treated with gefitinib or erlotinib [18]. MET is a proto-oncogene that encodes a transmembrane tyrosine kinase receptor which binds to a ligand called the hepatocyte growth factor (HGF). The ligand-bound receptor that induces receptor dimerization, phosphorylation and PI3K activation, resulting in persistent activation of the downstream pathway that overcomes the inhibition by EGFR TKI [19]. Amplification of the MET gene is involved in the invasion, metastasis and angiogenesis of tumors [20].

In addition, less common somatic gene mutations, such as HER2 [21], HER4 [22], BRAF [23] and PIK3CA [24] are also found in the EGFR pathways. Other receptor tyrosine kinases such as AXL [25] are also implicated in the acquired resistance to EGFR TKI. Taken together, some of these EGFR gene mutations activate the EGFR signaling pathway and promote EGFR-mediated pro-survival and anti-apoptotic signals through the downstream targets. However, whether these less common gene mutations represent predictive biomarkers of interest and promising therapeutic targets in patients with EGFR-mutation positive NSCLC remain an area of ongoing research. It is possible that future targeted therapies can take advantage of these additional gene mutations in the EGFR signaling pathway. For purpose of simplicity, these downstream gene mutations are not addressed in this minireview. Interested readers are encouraged to consult further references.

In summary, both exon 19 gene deletions and exon 21 L858R gene mutations result in the activation of the tyrosine kinase domain. These mutations are associated with sensitivity (i.e. sensitizing mutations) to small molecule EGFR TKIs. These four major types of gene mutations seldom occur simultaneously. Despite the high response rate and prolonged progression-free survival in patients with EGFR gene mutations treated with first-generation EGFR TKIs (such as gefitinib and erlotinib), about $50 \%$ of these patients will develop the acquired T790M mutation $[5,12,15]$. The presence of a de novo T790M mutation (i.e. primary resistance to first-line EGFR TKI therapy) is predictive for poor survival outcome associated with EGFR TKIs [16-18].

\section{Targeted Therapy against EGFR Protein and EGFR Gene Mutations}

There are two types of EGFR targeted therapy: anti-EGFR monoclonal antibodies that bind to the extracellular domain of the EGFR protein and the small molecule TKIs that bind to the intracellular 


\begin{tabular}{|c|c|c|c|c|c|}
\hline $\begin{array}{c}\text { EGFR } \\
\text { TKI/dosing }\end{array}$ & FDA approved indications & Interaction with PPI or H2A & $\begin{array}{l}\text { Drug-food } \\
\text { interaction }\end{array}$ & Adverse effects & $\begin{array}{c}\text { Hepatic or renal } \\
\text { adjustment }\end{array}$ \\
\hline $\begin{array}{c}\text { Gefitinib } \\
250 \text { mg po qday }\end{array}$ & $\begin{array}{l}\text { First-line therapy in metastatic } \\
\text { NSCLC with EGFR exon } 19 \\
\text { deletions or exon } 21(\text { L858R) } \\
\text { substitution mutations }\end{array}$ & $\begin{array}{l}\mathrm{PPI} \text { or } \mathrm{H} 2 \mathrm{~A} \text { : may decrease } \\
\text { serum conc. of gefitinib. } \\
\text { Monitor therapy }\end{array}$ & $\begin{array}{l}\text { Give with or } \\
\text { without } \\
\text { food }\end{array}$ & $\begin{array}{l}\text { Dermatologic (including pustular } \\
\text { rash, dry skin, paronychia): } 58 \% \\
\text { Diarrhea: } 35-47 \% \\
\text { Fever: } 9 \% \\
\text { Ocular: } 7 \%\end{array}$ & No adjustment needed \\
\hline $\begin{array}{c}\text { Erlotinib } \\
150 \mathrm{mg} \text { po daily }\end{array}$ & $\begin{array}{l}\text { First-line therapy in metastatic } \\
\text { NSCLC with EGFR exon } 19 \\
\text { deletions or exon } 21(L 858 R) \\
\text { mutations. } \\
\text { Maintenance therapy in } \\
\text { metastatic NSCLC after } 4 \text { cycles } \\
\text { of platinum-based first-line } \\
\text { chemotherapy } \\
\text { Second or third-line therapy in } \\
\text { metastatic NSCLC }\end{array}$ & $\begin{array}{l}\text { H2A: May decrease the } \\
\text { serum conc. of erlotinib } \\
\text { Avoid } \mathrm{H} 2 \mathrm{~A} \text { concurrently in pts } \\
\text { receiving erlotinib. Administer } \\
\text { erlotinib } 10 \text { hrs after the } \\
\mathrm{H} 2 \mathrm{Aan} \text { at least } 2 \text { hours prior } \\
\text { to next dose of } \mathrm{H} 2 \mathrm{~A} \\
\mathrm{PPI} \text { : May decrease the serum } \\
\text { conc. of erlotinib, avoid PPI }\end{array}$ & $\begin{array}{l}\text { Give } \\
\text { without food } \\
\text { Avoid concomitant } \\
\text { PPI }\end{array}$ & $\begin{array}{l}\text { Skin rash: } 49 \%-85 \% \\
\text { Paronychia : } 4 \%-16 \% \\
\text { Diarrhea: } 20 \%-62 \% \\
\text { Fever: } \leq 11 \% \\
\text { Weakness: } \leq 53 \% \text {, } \\
\text { Back pain: } 19 \% \text {, Arthralgia: } \leq 13 \% \\
\text { Musculoskeletal pain: } 11 \% \\
\text { Conjunctivitis: } 12 \% \text { - } 18 \% \\
\text { Keratoconjunctivitis sicca: } 12 \%\end{array}$ & $\begin{array}{l}\text { No information } \\
\text { If total bilirubin }>3 \\
\text { times ULN and/or } \\
\text { transaminases }>5 \text { times } \\
\text { ULN during use: consider } \\
\text { discontinuing }\end{array}$ \\
\hline $\begin{array}{c}\text { Afatinib } \\
40 \mathrm{mg} \text { po daily }\end{array}$ & $\begin{array}{l}\text { First-line therapy for patients who } \\
\text { have metastatic NSCLC tumors } \\
\text { with EGFR exon } 19 \text { deletions or } \\
\text { exon } 21 \text { L858R mutations }\end{array}$ & No information for $\mathrm{H} 2 \mathrm{~A}$ or $\mathrm{PPI}$ & Give without food & $\begin{array}{l}\text { Acneiform eruption: } 90 \% \\
\text { Paronychia: } 58 \% \text { xeroderma: } 31 \% \\
\text { pruritus: } 21 \% \\
\text { Conjunctivitis: } 11 \% \\
\text { Fever: } 12 \%\end{array}$ & $\begin{array}{l}\mathrm{CrCl}>60 \mathrm{~mL} / \mathrm{min} \text { : dose } \\
\text { adjustment not necessary } \\
\mathrm{CrCl}<60 \mathrm{~mL} / \mathrm{min} \text { : caution } \\
\text { and adjust if necessary. } \\
\text { Withhold therapy for } \\
\geq \text { grade } 3 \text { hepatic } \\
\text { dysfunction } \\
\text { Child-Pugh class A or B: } \\
\text { no dosage adjustment }\end{array}$ \\
\hline
\end{tabular}

Key: Conc= concentration; $\mathbf{H} 2 \mathbf{A}=\mathrm{H} 2$ antagonist; $\mathbf{P P I}=$ proton pump inhibitor; $\mathbf{p t s}=$ patients; $\mathbf{U L N}=$ upper limit normal

Table 1: Summary of current FDA approved small molecule tyrosine kinase inhibitors (TKIs) against mutation-positive epidermal growth factor receptor (EGFR) in advanced or metastatic non-small cell lung cancers.

tyrosine kinase domain with activating gene mutations. Together, these inhibitors act on a series of signaling pathways that mediate cell survival, proliferation, metastasis and angiogenesis. Of note, there is a fundamental clinical difference between anti-EGFR monoclonal antibodies and EGFR TKIs: anti-EGFR monoclonal antibodies such as cetuximab (Erbitux ${ }^{\infty}$, Eli Lilly and Bristol-Myers Squibb, U.S.) and panitumumab (Vectibix ${ }^{\oplus}$, Amgen, U.S.) currently are not approved by U.S. Food and Drug Administration (FDA) indicated in the treatment of advanced or metastatic NSCLC. On the contrary, current FDAapproved EGFR TKIs for advanced NSCLC patients with activating or sensitizing EGFR gene mutations include gefitinib (Iressa ${ }^{\circ}$, AstraZeneca Inc.), erlotinib (Tarceva ${ }^{\circledR}$, Genentech, U.S.) and afatinib (Gilotrif ${ }^{\infty}$, Boehringer Ingelheim. U.S). The comparison of each EGFR TKI in terms of FDA approved indications, adverse effects, drug/food interactions is summarized in Table 1 .

According to current U.S. National Comprehensive Cancer Network (NCCN) guidelines [26], first-line treatment for advanced or metastatic non-squamous NSCLC in patients with Eastern Cooperative Oncology Group (ECOG) performance status 0-1 (0=asymptomatic; $1=$ symptomatic but completely ambulatory) and negative or unknown epidermal growth factor receptor (EGFR) gene mutation is a platinumbased two-drug combination regimen. On the other hand, in nonsquamous NSCLC patients who have known or documented activating (or sensitizing) EGFR gene mutations, they benefit from first-line EGFR TKI therapy rather than chemotherapy [26].

Historically, high levels of EGFR gene expression were initially observed in metastatic NSCLC across all histology types and provided the initial impetus for early lung cancer trials targeting the EGFR pathway [12,14-17]. EGFR gene mutations were subsequently identified in select patients after clinical benefit to EGFR TKI was observed in $2004[10,27]$. Evaluation of tumor specimens in these patients led to the identification of two common mutations in EGFR gene, the exon 19 deletion and the exon 21 L858R missense mutation, both of which can be readily targeted by first-generation reversible EGFR TKIs such as gefitinib and erlotinib and second-generation TKI such as afatinib [27-29].

Erlotinib is the current EGFR TKI agent of choice in U.S. for patients with sensitizing EGFR gene mutations because of the restricted access of gefitinib. Of note, although gefitinib was shown to delay disease progression over placebo in the second and third-line settings (3.0 vs. 2.6 months, $\mathrm{P}=0.0006$ ) in two phase II trials, IDEAL-1 [28] and IDEAL-2 [30], the lack of overall survival benefit (5.6 vs. 5.1 months, $\mathrm{P}=0.087$ ) in the confirmatory phase III ISEL trial prompted the FDA's withdrawal of gefitinib's accelerated approval. Gefitinib is now restricted in patients already on this medication and continue to benefit from it (enrollment through the Iressa ${ }^{\circ}$ Access program) whereas in Europe and Asia, it is still approved or used for locally advanced and metastatic NSCLC with activating EGFR mutations. In U.S., no new patients can be initiated with gefitinib unless they are enrolled in clinical trials.

Afatinib is a newly FDA approved second-generation reversible oral TKI agent that inhibits EGFR (HER1), HER2 and HER4 (HER3 has no intrinsic tyrosine kinase activity). It is FDA approved for the first-line treatment of metastatic non-squamous NSCLC patients with sensitizing EGFR mutations. It is worth pointing out that despite the clinical efficacy of these EGFR TKIs, almost all patients who initially responded to EGFR TKI treatment (duration of response may last for $10-14$ months) will inevitably experience disease progression and become refractory to TKI therapy [20,29]. Preclinical studies of afatinib demonstrated that it was more effective than erlotinib and gefitinib in inhibiting the tumors harboring the L858R and T790M mutants [31]. Additionally, it retained significant in vitro and in vivo activity against the T790M mutations [32]. However, how much of this pharmacologic activity translates to clinical benefit currently remains unknown.

It is important to point out that the first-generation reversible TKIs such as gefitinib and erlotinib do not bind to EGFR receptors with T790M gene mutations which may also occur in patients who have not 
Citation: Chung C (2014) Tyrosine Kinase Inhibitors for EGFR Gene Mutation-Positive Non-Small Cell Lung Cancers: An Update for Recent Advances in Therapeutics. J Pharmacovigilance 2: 155. doi:10.4172/2329-6887.1000155

Page 4 of 8

\begin{tabular}{|c|c|c|c|}
\hline Treatment options & Trial & Dosing schedule/clinical efficacy & Adverse effects \\
\hline \multicolumn{4}{|c|}{ Chemotherapy + EGFR TKI } \\
\hline & $\begin{array}{l}\text { INTACT I [40] } \\
\text { Iressa NSCLC Trial Assessing } \\
\text { Combination Treatment } \\
\text { Phase III randomized, double-blind, } \\
\text { placebo-controlled, multicenter trial } \\
n=1,093 \\
\text { Chemotherapy-naive patients with } \\
\text { unresectable stage III or IV NSCLC } \\
\text { End points included OS (primary), TTP, } \\
\text { RR and safety evaluation }\end{array}$ & $\begin{array}{l}\text { Up to } 6 \text { cycles of cisplatin } 80 \mathrm{mg} / \mathrm{m}^{2} \text { i.v. on day } 1 \\
\text { and gemcitabine } 1,250 \mathrm{mg} / \mathrm{m}^{2} \mathrm{i} . \mathrm{v} \text {. on day } 1 \text { and } 8 \\
\text { q3 weeks plus either gefitinib } 500 \mathrm{mg} \text { p.o. daily, } \\
\text { gefitinib } 250 \mathrm{mg} \text { p.o. daily or placebo } \\
\text { Daily gefitinib or placebo continued until disease } \\
\text { progression } \\
\text { No difference in efficacy end points between the } \\
\text { treatment groups } \\
\text { (gefitinib } 500 \mathrm{mg} \text { po daily, gefitinib } 250 \mathrm{mg} \text { po } \\
\text { daily and placebo respectively) } \\
\text { Median survival times were } 9.9,9.9 \text {, and } 10.9 \\
\text { months respectively } \\
\text { Median TTP: } 5.5,5.8 \text {, and } 6.0 \text { months } \\
\text { respectively } \\
\text { RR: } 49.7 \%, 50.3 \% \text {, and } 44.8 \% \text { respectively }\end{array}$ & $\begin{array}{l}\text { No significant unexpected adverse } \\
\text { events were seen }\end{array}$ \\
\hline & $\begin{array}{l}\text { INTACT II [41] } \\
\text { Phase III, randomized, placebo- } \\
\text { controlled, double-blind trial in } \\
\text { chemotherapy-naive patients with } \\
\text { advanced NSCLC } \\
\mathrm{n}=1,037 \\
\text { End points included OS, TTP, response } \\
\text { rate, and safety evaluation }\end{array}$ & $\begin{array}{l}\text { Patients received paclitaxel } 225 \mathrm{mg} / \mathrm{m}^{2} \text { i.v. and } \\
\text { carboplatin AUC } 6 \mathrm{q} 3 \text { wks plus gefitinib } 500 \mathrm{mg} \\
\text { po daily, gefitinib } 250 \mathrm{mg} \text { po daily or placebo. } \\
\text { After a maximum of } \\
6 \text { cycles, gefitinib or placebo continued until } \\
\text { disease progression } \\
\text { No difference in OS (median, } 8.7,9.8 \text {, and } 9.9 \\
\text { months for gefitinib } 500 \mathrm{mg} \text { po daily, } 250 \mathrm{mg} \\
\text { po daily, and placebo respectively), TTP or RR } \\
\text { between arms }\end{array}$ & $\begin{array}{l}\text { Dose-related diarrhea and skin toxicity in } \\
\text { gefitinib-treated pts } \\
\text { No significant/unexpected safety findings } \\
\text { from combination with chemotherapy }\end{array}$ \\
\hline & $\begin{array}{l}\text { TRIBUTE [42] } \\
\text { Phase III, randomized, } \\
\text { double-blind, multicenter trial in } \\
\text { previously untreated patients with } \\
\text { advanced NSCLC } \\
\mathrm{n}=1,059\end{array}$ & $\begin{array}{l}\text { Pts received either erlotinib or placebo in } \\
\text { combination with paclitaxel } \\
200 \mathrm{mg} / \mathrm{m}^{2} \text { i.v. over } 3 \mathrm{~h} \text { and carboplatin AUC } 6 \text { i.v. } \\
\text { Median survival for pts treated with erlotinib was } \\
10.6 \mathrm{v} 10.5 \mathrm{months} \text { for placebo (hazard ratio, } \\
0.99 ; 95 \% \mathrm{Cl}, 0.86 \text { to } 1.16 ; \mathrm{P}=0.95 \text { ) } \\
\text { No difference in OR or median TTP }\end{array}$ & $\begin{array}{l}\text { Erlotinib and placebo arms were } \\
\text { equivalent in adverse events (except } \\
\text { rash and diarrhea) }\end{array}$ \\
\hline & $\begin{array}{l}\text { TALENT (Tarceva Lung } \\
\text { Cancer Investigation trial) [43] } \\
\text { Phase III, randomized, double-blind, } \\
\text { placebo-controlled, multicenter trial } \\
\text { Primary end point was OS } \\
\text { Secondary end points included TTP, RR, } \\
\text { duration of response, and QOL } \\
n=1,172 \\
\text { Baseline demographic and disease } \\
\text { characteristics were } \\
\text { well balanced }\end{array}$ & $\begin{array}{l}\text { Intervention arm: erlotinib } 150 \mathrm{mg} \text { p.o. daily } \\
\text { Comparator arm: placebo, combined with up to } \\
\text { six } 21 \text {-day cycles of } \\
\text { chemotherapy (gemcitabine } 1,250 \mathrm{mg} / \mathrm{m}^{2} \text { i.v. on } \\
\text { days } 1 \text { and } 8 \text { and cisplatin } 80 \mathrm{mg} / \mathrm{m}^{2} \text { on day } 1 \\
\text { No differences in OS, TTP, RR, duration of } \\
\text { response, and QOL } \\
\text { In a small group of patients who had never } \\
\text { smoked, OS and PFS were increased in the } \\
\text { erlotinib group; no other subgroups were found } \\
\text { more likely to benefit }\end{array}$ & $\begin{array}{l}\text { Erlotinib with chemotherapy } \\
\text { was generally well tolerated } \\
\text { Incidence of adverse events was similar } \\
\text { between arms, except for } \\
\text { an increase in rash and diarrhea with } \\
\text { erlotinib (generally mild) }\end{array}$ \\
\hline \multicolumn{4}{|c|}{ Chemotherapy $\rightarrow$ EGFR TKI } \\
\hline & $\begin{array}{l}\text { SATURN } \\
\text { Sequential Tarceva in Unresectable } \\
\text { NSCLC (SATURN) study [44] } \\
n=1,949 \text { (enrolled) } \\
\text { Multi-center, randomized, double-blind } \\
\text { phase III trial in pts with unresectable or } \\
\text { metastatic NSCLC } \\
\text { Pts were not allowed to have been } \\
\text { previously treated with chemotherapy or } \\
\text { EGFR TKIs or have uncontrolled brain } \\
\text { metastases. } \\
\text { In the erlotinib and } \\
\text { placebo-treated groups, most patients } \\
\text { were male ( } 73 \text { and } 75 \%, \text { respectively), } \\
\text { Caucasian (84 and } 83 \%, \text { respectively), } \\
\text { performance status } 1 \text { ( } 69 \text { and } 68 \%, \\
\text { respectively), current or } \\
\text { former smokers ( } 83 \text { and } 83 \%, \\
\text { respectively }\end{array}$ & $\begin{array}{l}\text { Following completion of } 4 \text { cycles of standard } \\
\text { chemotherapy (cisplatin/carboplatin plus another } \\
\text { agent), pts }(n=889 \text { ) without disease progression, } \\
\text { intolerable toxicity or poor PS (ECOG } \leq 2 \text { ) were } \\
\text { randomized to receive erlotinib } 150 \mathrm{mg} \text { po daily ( } \mathrm{n} \\
=438 \text { ) or placebo and standard supportive care } \\
\text { ( } \mathrm{n}=451 \text { ) until disease progression or intolerable } \\
\text { toxicity } \\
\text { Pts that received maintenance erlotinib, had } \\
\text { significantly prolonged PFS compared with } \\
\text { patients treated with placebo (12.3 vs. } 11.1 \\
\text { weeks; } \\
\text { HR: } 0.71 ; 95 \% \text { Cl: } 0.62-0.82 ; p<0.0001) \\
\text { The few pts with documented EGFR-activating } \\
\text { mutations that received erlotinib had a more } \\
\text { impressive } \\
\text { median PFS ( } 44 \text { vs. } 14 \text { weeks; HR: } 0.10 ; 95 \% \\
\text { Cl: } 0.04-0.25 ; p<0.0001) \text { than pts without } \\
\text { activating mutations (HR: } 0.78 ; 95 \% \text { Cl: } 0.63- \\
0.96 ; p=0.0185) \\
\text { Median OS was significantly prolonged in the } \\
\text { group receiving } \\
\text { erlotinib ( } 12 \text { months) vs. placebo ( } 11 \text { months; HR: } \\
0.81 ; 95 \% \text { Cl: } 0.70-0.95 ; p=0.0088)\end{array}$ & $\begin{array}{l} \\
\text { T5\% of patients receiving erlotinib and } \\
20 \% \text { of patients receiving placebo had } \\
\text { adverse effects } \\
\text { Most events on the erlotinib arm: } \leq \text { grade } \\
2 \text { rash (60\%) or diarrhea (18\%) } \\
\text { No difference in overall QOL between the } \\
\text { two groups. }\end{array}$ \\
\hline
\end{tabular}




\begin{tabular}{|c|c|c|c|}
\hline Treatment options & Trial & Dosing schedule/clinical efficacy & Adverse effects \\
\hline \multicolumn{4}{|c|}{ Chemotherapy with intermittent EGFR TKI } \\
\hline & $\begin{array}{l}\text { FAST- ACT trial [45] } \\
\text { Multicenter trial } \\
n=154 \text { (median age: } 57,94 \% \text { Asians) } \\
\text { chemonaïve stage IIIB/IV } \\
\text { PS }=0 / 1 \text { and adequate organ function }\end{array}$ & $\begin{array}{l}\text { Intervention arm: Erlotinib } 150 \mathrm{mg} \text { p.o. daily + } \\
\text { chemotherapy } \\
\text { Comparator arm: Placebo p.o. days } 15-28+ \\
\text { chemotherapy } \\
\text { Chemotherapy: } \\
\text { Gemcitabine } 1,250 \mathrm{mg} / \mathrm{m}^{2} \text { i.v. days } 1,8+\text { cisplatin } \\
75 \mathrm{mg} / \mathrm{m}^{2} \text { i.v. or carboplatin AUC } 5 \text { i.v. day } 1 \text { for } \\
\text { a maximum of } 6 \text { cycles (cycle to repeat q } 4 \text { weeks) } \\
\text { Responding pts continued to receive erlotinib or } \\
\text { until disease progression or intolerable toxicity } \\
\text { Primary endpoint was non-progression rate (= } \\
\text { CR+PR+SD) } \\
\text { Median number of treatment cycles received: } 6 \\
\text { for chemo + erlotinib; } \\
5 \text { for chemo + placebo } \\
\text { Statistically significant improvement in PFS } \\
\text { (p=0.005) was observed in the erlotinib + } \\
\text { chemotherapy arm }\end{array}$ & $\begin{array}{l}\text { Rash-like events: } 66 \% \text { in chemo + } \\
\text { erlotinib arm; } \\
35 \% \text { in chemo + placebo arm } \\
\text { Diarrhea: } 24 \% \text { chemo + erlotinib arm ; } \\
18 \% \text { in chemo + placebo arm } \\
\text { Most common grade } 3-5 \text { adverse events } \\
\text { (chemo + erlotinib vs. chemo + placebo): } \\
\text { neutropenia ( } 20 \% \text { vs. } 15 \%) \\
\text { anemia ( } 8 \% \text { vs. } 6 \%) \\
\text { thrombocytopenia ( } 5 \% \text { vs. } 5 \%) \\
\text { vomiting ( } 3 \% \text { vs. } 8 \%) \\
\text { Overall safety profiles were similar } \\
\text { between the two arms }\end{array}$ \\
\hline
\end{tabular}

Key: $\mathbf{A U C}=$ area under concentration/time curve; $\mathbf{C R}=$ complete response; $\mathbf{E C O G}=$ Eastern Cooperative Oncology $\mathrm{Group}(\mathrm{ECOG}) ; \mathbf{P F S}=$ progression-free survival PR=partial response; PS=performance status; $\mathbf{P t s}=$ patients; $\mathbf{R R}=$ response rate; $\mathbf{S D}=$ stable disease; $\mathbf{T T P}=$ time to disease progression

Table 2: Summary of major clinical trials to test clinical efficacy of chemotherapy and EGFR TKIs in different treatment sequences in advanced NSCLC patients.

received TKI therapy. These patients will not respond to initial treatment with gefitinib or erlotinib and are deemed to have primary or de novo resistance [33]. However, some studies suggest that the presence of T790M gene mutations may not necessarily imply a worse treatment outcome compared to patients without the T790 gene mutations [3335]. At present, afatinib does not have the FDA labeled indication for use in patients with T790M gene mutations. Moreover, T790M gene mutation should not be regarded as a predictive biomarker for afatinib.

\section{Clinical Efficacy of TKI Therapy in Metastatic NSCLC}

The place of therapy for EGFR TKIs underwent major changes in the last decade. Initial studies with gefitinib and erlotinib as single agents demonstrated biologic and clinical activity in only a relatively limited subset of unselected NSCLC patients in the second or third line setting after failure of first-line platinum-based chemotherapy [36]. For instance, erlotinib monotherapy was shown to improve progressionfree survival $(2.2$ vs. 1.8 months, $P<0.001)$ and overall survival over best supportive care (6.7 vs. $4.7, P<0.001)$ in unselected NSCLC patients with advanced disease who had failed one or two prior lines of chemotherapy (BR 21 trial) [37].

Early studies showed that activating EGFR gene mutations are most common in patients with adenocarcinoma histology, women, never or light smokers, and those of Asian ethnicity. As a result, these patients exhibited increased response to EGFR TKIs. The overall response rate may be as high as $80 \%$ in selected patients with gene mutations and $10-20 \%$ in unselected populations. The prevalence of sensitizing EGFR mutations (mainly exon19 deletion and exon 21 L858R mutations) is approximately 20-40\% among Asians and 10\% among Caucasians to treatment with first-generation, reversible EGFR TKIs such as gefitinib or erlotinib. Of important note, selection of the patient population with EGFR gene mutations upfront is necessary to maintain efficacy of TKIs as the first line therapy in metastatic setting. In unselected patients in the early clinical trials, EGFR TKIs did not show additional survival benefit when added to platinum-doublet chemotherapy, nor have they shown superiority to single-agent chemotherapy in the salvage treatment setting in unselected patients [29,37-39].

More questions now arise as to whether the survival benefit is restricted to Asian patients or non-smokers alone. The recent randomized, multicenter, international LUX-Lung 3 study [29] suggested that frontline or initial EGFR TKI therapy with afatinib is associated with improved progression-free survival compared to cisplatinpemetrexed chemotherapy doublet, regardless of race. In addition, in the EURTAC [38] (European Tarceva versus chemotherapy) study, erlotinib is associated with improved survival outcome in European patients. Recently, the American Society of Clinical Oncology (ASCO) endorsed the consensus guideline of several professional organizations for EGFR gene testing to all patients with lung adenocarcinoma (or mixed lung cancers with an adenocarcinoma component), regardless of characteristics such as smoking status, gender or race [39].

Current NCCN guidelines [26] recommend erlotinib as a firstline therapy agent for advanced or metastatic NSCLC patients with sensitizing mutations. Erlotinib should not be given as a first-line therapy to patients negative for these mutations or with unknown EGFR status. Afatinib is also recommended as a first-line agent for select patients with sensitizing mutations. In patients who have experienced disease progression either during or after first-line therapy, single agent docetaxel, pemetrexed or erlotinib are established second-line agents. Erlotinib is superior to best supportive care and afatinib may also be used in select patients with sensitizing EGFR mutations. Erlotinib is also recommended as third-line agent. In general, erlotinib, gefitinib, afatinib are recommended for continuation after disease progression in patients with sensitizing EGFR mutations. Erlotinib has a category two NCCN recommendation for maintenance therapy in patients without disease progression after 4-6 cycles of first-line platinum-based chemotherapy [26].

\section{Combination of TKI Therapy with Chemotherapy}

There was initial interest in whether combination of EGFR TKI and chemotherapy can enhance patient survival after their FDA approval in the last decade. However, four large front line trials [40-43] (Table 2) failed to demonstrate a survival advantage with the first-line use of either gefitinib or erlotinib in combination with chemotherapy. Based on the survival benefit of erlotinib in previously treated patients, there was interest in determining whether erlotinib treatment is more effective immediately following the completion of first-line chemotherapy. The Sequential Tarceva in Unresectable NSCLC (SATURN) trial [44] was designed to investigate the efficacy of maintenance erlotinib treatment until the time of progression. Erlotinib demonstrated significant improvement in overall survival in maintenance therapy. 
A recent study [45] of intermittent TKI therapy with chemotherapy had suggested its preliminary efficacy but since the current standard of care still favors EGFR TKI for maintenance therapy, its role requires validation in long-term studies. Another study [46] from a single institution suggested that when patients with EGFR mutations progressed on erlotinib and when progression occurred in only a limited number of sites $(<4)$, the same therapy or local disease control (e.g. stereotactic body radiation therapy in CNS disease) may be offered. Patients with EGFR gene mutations who have disease progression often experience disease flare-up when the EGFR TKI is discontinued [47].

In addition, studies [48-50] suggest that instead of first-line chemotherapy, erlotinib or gefitinib or afatinib should be the first-line systemic therapy in patients with EGFR gene mutations documented before starting first-line therapy. Progression-free survival (overall survival is not statistically significant) is improved with the use of these EGFR TKIs in patients with sensitizing or activating EGFR mutations compared to standard chemotherapy. In the recent LUX- Lung 3 trial, afatinib improved the quality of life compared to those received cisplatin/pemetrexed chemotherapy. However, in the trial, afatinib was associated with 4 deaths whereas chemotherapy had no treatmentrelated deaths [29].

To summarize, EGFR gene mutations of non-small cell lung cancer (NSCLC) patients are predictive (improved progression-free survival and response rate) when treated with EGFR TKIs such as gefitinib and erlotinib in the first-line therapy of metastatic disease compared to conventional platinum-based chemotherapy. EGFR TKIs are also used in second-, third-line or maintenance therapy.

\section{Toxicities of EGFR TKIs}

The most frequent adverse events in clinical trials of afatinib were diarrhea, rash or acne $(78 \%-97 \%$ of patients treated in the LUX-Lung trials). Stomatitis and nail effects also appeared frequently. These toxicities were similar to those observed in erlotinib and gefitinib trials. Toxicities of afatinib could be managed by dose reductions to $40 \mathrm{mg}$ or $30 \mathrm{mg}$, and only less than $10 \%$ of patients (8\% in LUX-Lung 1 [51], and 9\% in LUX-Lung 2 [52]) required afatinib discontinuation due to drugrelated adverse events. Side effects of gefitinib and erlotinib are usually mild to moderate, and most commonly manifest as dose-dependent skin rash and diarrhea.

\section{Genetic Testing}

In the setting of lung cancer resection specimens, EGFR testing is recommended for adenocarcinomas and mixed lung cancers with an adenocarcinoma component, regardless of histologic grade. EGFR testing is not recommended in lung cancers that lack any adenocarcinoma component. In squamous NSCLC, EGFR gene mutation testing is generally not required, but can be considered in never smokers, small biopsy specimen or mixed histology. If EGFR gene mutation is confirmed during first-line chemotherapy, patient may either: (1) complete chemotherapy; or (2) interrupt chemotherapy, start erlotinib or afatinib or (3) add erlotinib or afatinib to chemotherapy (NCCN category 2B recommendation) [26].

Various DNA mutational analyses can be used to determine the EGFR mutation status in tumor cells: direct sequencing of DNA corresponding to exon 18-21, PCR-based mutational screening assays and next generation sequencing can be used [53]. A number of central or reference laboratories offer EGFR genotyping of exons 18- 21. Typical examples of FDA-approved qualitative PCR testing include: cobas $^{\oplus}$ EGFR Mutation Test (Roche Molecular Diagnostics, Pleasanton,
CA), therascreen EGFR RGQ PCR kit (Qiagen, Valencia, CA) and some others.

\section{Future of Anti-EGFR TKI Therapy with Chemotherapy}

At present, combination therapy of anti-EGFR TKIs with chemotherapy in unselected NSCLC patients have not resulted in added value. In selected patients with sensitizing EGFR gene mutations, combination therapy of anti-EGFR TKIs with chemotherapy has been shown to improve survival outcome [54]. Combination therapy may be necessary in patients with a large tumor burden. In addition, treatment beyond disease progression after TKI failure with combination therapy of anti-EGFR TKI and chemotherapy has been reported, necessitating more studies into the novel combination therapies to address these acquired mechanisms of resistance [55].

Recently, a small molecule TKI, tivantinib, and the monoclonal antibody, onartuzumab, have both been evaluated in the second-line setting in EGFR-TKI naïve patients after chemotherapy failure. In the phase 3 trial, combination therapy of onartuzumab and erlotinib was not shown to improve PFS (2.7 vs. 2.6 months, $\mathbf{P}=0.92$ ) or objective response rate $8.4 \%$ vs. $9.6 \%, \mathbf{P}=0.63$ ) [56]. Despite this negative finding, many ongoing trials will likely shed some light to elucidate the additional roles of EGFR TKIs with other agents and how these agents could be sequenced to optimized treatment outcome.

The role of antiangiogenesis is investigated in an open-label, randomized phase 2 Japanese study. Chemotherapy naïve patients ( $\mathrm{n}=154)$ with stage IIIB/IV non-squamous NSCLC with activating EGFR gene mutation either received erlotinib $150 \mathrm{mg}$ orally once-aday plus bevacizumab $15 \mathrm{mg} / \mathrm{kg}$ i.v. every 3 weeks $(\mathrm{n}=77)$ or erlotinib $150 \mathrm{mg}$ orally once-a-day monotherapy $(\mathrm{n}=77)$ as first-line therapy until disease progression or intolerable toxicity. Median progressionfree survival was 16.0 months (95\% CI $13.9-18.1)$ with erlotinib plus bevacizumab and 9.7 months $(5 \cdot 7-11 \cdot 1)$ with erlotinib monotherapy (hazard ratio $0.54,95 \%$ CI $0.36-0.79 ; \mathrm{P}=0.0015$ ), suggesting that erlotinib plus bevacizumab combination could be a new first-line regimen in EGFR mutation-positive NSCLC. Further study of the regimen is warranted [57].

Combination of EGFR TKI (e.g. erlotinib) and anti-EGFR monoclonal antibody (e.g. cetuximab) did not seem to result in survival benefit in patients who acquired resistance to first-generation EGFR TKIs [58], while in another phase Ib study [59], the combination of afatinib and cetuximab resulted in response rate in about $30 \%$ of NSCLC patients who developed T790M gene mutations. More study is apparently needed to validate the role of this dual "EGFR blockage".

Recently, two interesting trials published their preliminary results on whether EGFR TKI should be continued during disease progression. In the phase III IMPRESS trial, 265 patients from 71 centers in Europe and Asia were enrolled and randomly assigned to cisplatin/pemetrexed plus gefitinib vs. cisplatin/pemetrexed plus placebo. $65 \%$ of patients were female and mean age was about 60 . Overall response rate was $31.6 \%$ for gefitinib vs $34.1 \%$ for chemotherapy, and the disease control rate was $84.2 \%$ vs $78.2 \%$, respectively. Overall survival data have not reached during study cut-off date. The study demonstrated that EGFR TKI should not be continued beyond progression. The standard treatment at progression remains platinum-based chemotherapy [31].

On the other hand, another phase II study (Aspiration) evaluated the safety and efficacy of erlotinib before and after disease progression in untreated Asian patients with EGFR-mutated NSCLC in 150 patients. 81 of those received erlotinib with a median 1-year progression-free 
survival (PFS) of 9.3 months. In patients who did not receive erlotinib after disease progression, median 1-year PFS was 7.2 months. Patients with exon 19 deletion and exon 21 L858R mutations had more favorable PFS than those without. Among the 207 patients evaluated for safety, $45.4 \%$ reported grade $\geq 3$ adverse events. The study suggested that even though there is a slight increase in the tumor on the assessment, if the treatment is well-tolerated, and if the patient remains asymptomatic, patient should not be switched to chemotherapy immediately, but continues until there is clear clinical progression [32]. More studies will be needed to address the place of therapy for EGFR TKI in disease progression.

\section{Conclusion}

The success of targeted agents in molecularly defined subsets of patients has radically changed the treatment paradigm of metastatic lung adenocarcinoma. It is becoming clinically relevant to re-biopsy tumor at recurrence and defines what therapeutic options are considered appropriate. To date, the most significant progress is for metastatic NSCLC patients whose tumors harbor EGFR mutations, in whom first-line treatment with EGFR TKIs led to improvement in survival outcomes compared to standard chemotherapy. As more clinical trials for EGFR TKI mature, better understanding may be gained through the use of these agents either alone or in combination with different therapeutic agents (e.g. chemotherapy) and in different sequences in improving treatment efficacy of metastatic lung adenocarcinoma.

\section{Disclosure}

No conflicts of interest to disclose.

\section{Funding}

None.

\section{References}

1. National Cancer Institute. SEER (Surveillance, Epidemiology and End Results) Statistics.

2. Edge S, Byrd DR, Compton CC, Fritz AG, Greene FL, et al. (2009) Cancer staging handbook. (7thedn), AJCC cancer staging manual. Springe, Germany.

3. Scagliotti GV, Fossati R, Torri V, Crinò L, Giaccone G, et al. (2003) Randomized study of adjuvant chemotherapy for completely resected stage I, II, or IIIA nonsmall-cell Lung cancer. J Natl Cancer Inst 95: 1453-1461.

4. Albain KS, Crowley JJ, Turrisi AT 3rd, Gandara DR, Farrar WB, et al. (2002) Concurrent cisplatin, etoposide, and chest radiotherapy in pathologic stage IIIB non-small-cell lung cancer: a Southwest Oncology Group phase II study, SWOG 9019. J Clin Oncol 20: 3454-3460.

5. Socinski MA, Evans T, Gettinger S, Hensing TA, Sequist LV, et al. (2013) Treatment of stage IV non-small cell lung cancer: Diagnosis and management of lung cancer, 3rd ed: American College of Chest Physicians evidence-based clinical practice guidelines. Chest 143: e341S-68S.

6. Schiller JH, Harrington D, Belani CP, Langer C, Sandler A, et al. (2002) Comparison of four chemotherapy regimens for advanced non-small-cell lung cancer. N Eng J Med 346: 92-98.

7. Bogdan S, Klämbt C (2001) Epidermal growth factor receptor signaling. Curr Biol 11: R292-295.

8. Bazley LA, Gullick WJ (2005) The epidermal growth factor receptor family. Endocr Relat Cancer 12 Suppl 1: S17-27.

9. Ciardiello F, Tortora G (2008) EGFR antagonists in cancer treatment. N Engl J Med 358: 1160-1174

10. Fujino S, Enokibori T, Tezuka N, Asada Y, Inoue S, et al. (1996) A comparison of epidermal growth factor receptor levels and other prognostic parameters in non-small cell lung cancer. Eur J Cancer 32A: 2070-2074.

11. Mendelsohn J, Baselga J (2006) Epidermal growth factor receptor targeting in cancer. Semin Oncol 33: 369-385.
12. Sharma SV, Bell DW, Settleman J, Haber DA (2007) Epidermal growth factor receptor mutations in lung cancer. Nat Rev Cancer 7: 169-181.

13. Wells A (1999) EGF receptor. Int J Biochem Cell Biol 31: 637-643.

14. Ciardiello F, Tortora G (2001) A novel approach in the treatment of cancer: targeting the epidermal growth factor receptor. Clin Cancer Res 7: 2958-2970.

15. Mitsudomi T, Yatabe $Y$ (2007) Mutations of the epidermal growth factor receptor gene and related genes as determinants of epidermal growth factor receptor tyrosine kinase inhibitors sensitivity in lung cancer. Cancer Sci 98: 1817-1824.

16. Sequist LV, Bell DW, Lynch TJ, Haber DA (2007) Molecular predictors of response to epidermal growth factor receptor antagonists in non-small-cell lung cancer. J Clin Oncol 25: 587-595.

17. Riely GJ, Pao W, Pham D, Li AR, Rizvi N, et al. (2006) Clinical course of patients with non-small cell lung cancer and epidermal growth factor receptor exon 19 and exon 21 mutations treated with gefitinib or erlotinib. Clin Cancer Res 12: 839-844.

18. Bean J, Brennan C, Shih JY, Riely G, Viale A, et al. (2007) MET amplification occurs with or without T790M mutations in EGFR mutant lung tumors with acquired resistance to gefitinib or erlotinib. Proc Natl Acad Sci USA 104: 20932 20937.

19. Engelman JA, Zejnullahu K, Mitsudomi T, Song Y, Hyland C, et al. (2007) MET amplification leads to gefitinib resistance in lung cancer by activating ERBB3 signaling. Science 316: 1039-1043.

20. Kosaka T, Yamaki E, Mogi A, Kuwano H (2011) Mechanisms of resistance to EGFR TKIs and development of a new generation of drugs in non-small-cell lung cancer. J Biomed Biotechnol 2011: 165214.

21. Shigematsu H, Takahashi T, Nomura M, Majmudar K, Suzuki M, et al. (2005) Somatic mutations of the HER2 kinase domain in lung adenocarcinomas. Cancer Res 65: 1642-1646.

22. Soung YH, Lee JW, Kim SY, Wang YP, Jo KH, et al. (2006) Somatic mutations of the ERBB4 kinase domain in human cancers. Int J Cancer 118: 1426-1429.

23. Naoki K, Chen TH, Richards WG, Sugarbaker DJ, Meyerson M (2002) Missense mutations of the BRAF gene in human lung adenocarcinoma. Cancer Res 62: 7001-7003.

24. Samuels Y, Wang Z, Bardelli A, Silliman N, Ptak J, et al. (2004) High frequency of mutations of the PIK3CA gene in human cancers. Science 304: 554.

25. Zhang Z, Lee JC, Lin L, Olivas V, Au V, et al. (2012) Activation of the AXL kinase causes resistance to EGFR-targeted therapy in lung cancer. Nat Genet 44: 852-860.

26. NCCN (2014) NCCN Practice guidelines in Oncology, Version 4. The Nationa Comprehensive Cancer Network, Fort Washington, PA.

27. Miller VA, Johnson DH, Krug LM, Pizzo B, Tyson L, et al. (2003) Pilot tria of the epidermal growth factor receptor tyrosine kinase inhibitor gefitinib plus carboplatin and paclitaxel in patients with stage IIIB or IV non-small-cell lung cancer. J Clin Oncol 21: 2094-2100.

28. Fukuoka M, Yano S, Giaccone G, Tamura T, Nakagawa K, et al. (2003) Multiinstitutional randomized phase II trial of gefitinib for previously treated patients with advanced non-small-cell lung cancer (The IDEAL 1 Trial) [Corrected]. J Clin Oncol 21: 2237-2246.

29. Sequist LV, Yang JC, Yamamoto N, O'Byrne K, Hirsh V, et al. (2013) Phase III study of afatinib or cisplatin plus pemetrexed in patients with metastatic lung adenocarcinoma with EGFR mutations. J Clin Oncol 31: 3327-3334.

30. Kris MG, Natale RB, Herbst RS, Lynch TJ Jr, Prager D, et al. (2003) Efficacy of gefitinib, an inhibitor of the epidermal growth factor receptor tyrosine kinase, in symptomatic patients with non-small cell lung cancer: a randomized trial. JAMA 290: 2149-2158.

31. Mok TSK, Wu Y, Nakagawa K, Kim S, Yang J, et al. (2014) Gefitinib/ Chemotherapy vs Chemotherapy in Epidermal Growth Factor Receptor (EGFR) Mutation-Positive Non-Small-Cell Lung Cancer (NSCLC) After Progression on First-Line Gefitinib: The Phase III Randomised IMPRESS Study. ESMO 2014 Madrid, Spain.

32. Park K, Tsai CM, Ahn MJ, Yu CJ, Kim SW, et al. (2012) ASPIRATION: firstline erlotinib (E) until and beyond RECIST progression (PD) in Asian patients (pts) with EGFR mutation-positive (mut+) NSCLC. 2012 ASCO Annual Meeting Chicago, Illinois. 
33. Rosell R, Molina MA, Costa C Simonetti S, Gimenez-Capitan A et al. (2011) Pretreatment EGFR T790M mutation and BRCA1 mRNA expression in erlotinib-treated advanced non-small-cell lung cancer patients with EGFR mutations. Clin Cancer Res 17: 1160-1168.

34. Gazdar AF (2009) Activating and resistance mutations of EGFR in non-smallcell lung cancer: role in clinical response to EGFR tyrosine kinase inhibitors. Oncogene 28 Suppl 1: S24-31.

35. Su KY, Chen HY, Li KC, Kuo ML, Yang JC, et al. (2012) Pretreatment epidermal growth factor receptor (EGFR) T790M mutation predicts shorter EGFR tyrosine kinase inhibitor response duration in patients with non-small-cell lung cancer. $J$ Clin Oncol 30: 433-440.

36. Shepherd FA, Tsao MS (2006) Unraveling the mystery of prognostic and predictive factors in epidermal growth factor receptor therapy. J Clin Oncol 24 1219-1220.

37. Shepherd FA, Rodrigues Pereira J, Ciuleanu T, Tan EH, Hirsh V, et al. (2005) Erlotinib in previously treated non-small-cell lung cancer. N Engl J Med 353: 123-132.

38. Rosell R, Carcereny E, Gervais R, Vergnenegre A, Massuti B, et al. (2011) Erlotinib versus chemotherapy as first-line treatment for patients with advanced EGFR mutation-positive non-small cell lung cancer (EURTAC): a mutlicentre, open-label, randomized phase 3 trial. Lancet Oncol 12: 735-742.

39. Leighl NB, Rekhtman N, Biermann WA, Huang J, Mino-Kenudson M, et al (2014) Molecular testing for selection of patients with lung cancer for epidermal growth factor receptor and anaplastic lymphoma kinase tyrosine kinase inhibitors: American Society of Clinical Oncology endorsement of the College of American Pathologists/International Association for the Study of Lung Cancer/ Association for Molecular Pathology Guideline. J Clin Oncol 32:3673-3679.

40. Giaccone G, Herbst RS, Manegold C, Scagliotti G, Rosell R, et al. (2004) Gefitinib in combination with gemcitabine and cisplatin in advanced non-smallcell lung cancer: a phase III trial--INTACT 1. J Clin Oncol 22: 777-784.

41. Herbst RS, Giaccone G, Schiller JH, Natale RB, Miller V, et al. (2004) Gefitinib in combination with paclitaxel and carboplatin in advanced non-small-cell lung cancer: a phase III trial-INTACT 2. J Clin Oncol 22: 785-794.

42. Reck M (2006) Beyond the TRIBUTE trial: integrating HER1/EGFR tyrosine kinase inhibitors with chemotherapy in advanced NSCLC. Future Oncol 2: 4751.

43. Gatzemeier U, Pluzanska A, Szczesna A, Kaukel E, Roubec J, et al. (2007) Phase III study of erlotinib in combination with cisplatin and gemcitabine in advanced non-small-cell lung cancer: the Tarceva Lung Cancer Investigation Trial. J Clin Oncol 25: 1545-1552.

44. Cappuzzo F, Ciuleanu T, Stelmakh L, Cicenas S, Szczésna A, et al. (2010) Erlotinib as maintenance treatment in advanced non-small-cell lung cancer: a multicentre, randomised, placebo-controlled phase 3 study. Lancet Oncol 11: 521-529.

45. Lee, JS, Ignacio J, Yu C, Zhou C, Wu Y, et al. (2008) FAST-ACT: A phase II randomized double-blind trial of sequential erlotinib and chemotherapy as first-line treatment in patients (pts) with stage IIIB/IV non-small cell lung cancer (NSCLC). J Clin Oncol 26: 8031.

46. Weickhardt AJ, Scheier B, Burke JM, Gan G, Lu X, et al. (2012) Local ablative therapy of oligoprogressive disease prolongs disease control by tyrosine kinase inhibitors in oncogene-addicted non-small-cell lung cancer. J Thorac Oncol 7: 1807-1814.

47. Chaft JE, Oxnard GR, Sima CS, Kris MG, Miller VA, et al. (2011) Disease flare after tyrosine kinase inhibitor discontinuation in patients with EGFR-mutan lung cancer and acquired resistance to erlotinib or gefitinib: implications for clinical trial design. Clin Cancer Res 17: 6298-6303.
48. Mitsudomi T, Morita S, Yatabe Y, Negoro S, Okamoto I, et al. (2010) Gefitinib versus cisplatin plus docetaxel in patients with non-small-cell lung cance harbouring mutations of the epidermal growth factor receptor (WJTOG3405): an open label, randomized phase 3 trial. Lancet Oncol 11: 121-128.

49. Maemondo M, Inoue A, Kobayashi K, Sugawara S, Oizumi S, et al. (2010) Gefitinib or chemotherapy for non-small-cell lung cancer with mutated EGFR. N Eng J Med 362: 2380-2388.

50. Zhou C, Wu YL, Chen G, Feng J, Liu XQ, et al. (2011) Erlotinib versus chemotherapy as first-line treatment for patients with advanced EGFR mutation-positive non-small-cell lung cancer (OPTIMAL, CTONG-0802): a multicentre, open-label, randomised, phase 3 study. Lancet Oncol 12: 735-742.

51. Miller VA, Hirsh V, Cadranel J, Chen YM, Park K, et al. (2010) Phase iib/iii double-blind randomized trial of afatinib (BIBW 2992, an irreversible inhibitor of egfr/her1 and her2) + best supportive care (bsc) versus placebo + bsc in patients with nsclc failing 1-2 lines of chemotherapy and erlotinib or gefitinib (lux-Lung 1) [abstract LBA1]. Ann Oncol 21: viii1.

52. Yang C, Shih J, Su W, Hsia T, Tsai C, et al. (2010) A phase II study of BIBW 2992 in patients with adenocarcinoma of the lung and activating EGFR/HER1 mutations (LUX-LUNG 2). 2010 ASCO Annual Meeting, Chicago, Illinois.

53. Li T, Kung HJ, Mack PC, Gandara DR (2013) Genotyping and genomic profiling of non-small-cell lung cancer: implications for current and future therapies. Clin Oncol 31: 1039-1049.

54. Shepherd FA, Rodrigues Pereira J, Ciuleanu T, Tan EH, Hirsh V, et al. (2005) Erlotinib in previously treated non-small-cell lung cancer. N Engl J Med 353: 123-132.

55. Thatcher N, Chang A, Parikh P, Rodrigues Pereira J, Ciuleanu T, et al. (2005) Gefitinib plus best supportive care in previously treated patients with refractory advanced non-small-cell lung cancer: results from a randomised, placebocontrolled, multicentre study (Iressa Survival Evaluation in Lung Cancer). Lancet 9496: 1527-1537.

56. Spigel DR, Edelman MJ, O'Byrne K, Paz-Ares L, Shames DS, et al. (2014) Onartuzumab plus erlotinib versus erlotinib in previously treated stage IIlb or IV NSCLC: results from the pivotal phase III randomized, multicenter, placebocontrolled METlung (OAM4971g) global trial. 2014 ASCO Annual Meeting, Chicago, Illinois.

57. Seto T, Kato T, Nishio M, Goto K, Atagi S, et al. (2014) Erlotinib alone or with bevacizumab as first-line therapy in patients with advanced non-squamous non-small-cell lung cancer harbouring EGFR mutations (JO25567): an openlabel, randomised, multicentre, phase 2 study. Lancet Oncol 15: 1236-1244.

58. Janjigian YY, Azzoli CG, Krug LM, Pereira LK, Rizvi NA, et al. (2011) Phase $\mathrm{I} / \mathrm{II}$ trial of cetuximab and erlotinib in patients with lung adenocarcinoma and acquired resistance to erlotinib. Clin Cancer Res 17: 2521-2527.

59. Janjigian YY, Groen HJ, Horn L, Smit EF, Fu Y, et al. (2011) Activity and tolerability of afatinib (BIBW 2992) and cetuximab in NSCLC patients with acquired resistance to erlotinib or gefitinib. 2011 ASCO Annual Meeting, Chicago, Illinois. 